\title{
Developing Soybean Protein Gel-Based Foods from Okara Using the Wet-Type Grinder Method
}

\author{
Yuya Arai ${ }^{1}$, Katsuyoshi Nishinari ${ }^{2}$ and Takao Nagano ${ }^{1, *}$ \\ 1 Department of Food Science, Faculty of Bioresources and Environmental Sciences, Ishikawa Prefectural \\ University, 1-308, Suematsu, Nonoich 921-8836, Japan; evian0429akyg@gmail.com \\ 2 Glyn O. Phillips Hydrocolloids Research Centre, School of Food and Biological Engineering, \\ Hubei University of Technology, Wuhan 430068, China; katsuyoshi.nishinari@gmail.com \\ * Correspondence: naganot@ishikawa-pu.ac.jp; Tel.: +81-76-227-7455; Fax: +81-76-227-7410
}

check for

updates

Citation: Arai, Y.; Nishinari, K.; Nagano, T. Developing Soybean Protein Gel-Based Foods from Okara Using the Wet-Type Grinder Method. Foods 2021, 10, 348. https://doi.org/ $10.3390 /$ foods 10020348

Academic Editor: Antonio Cilla

Received: 28 December 2020

Accepted: 1 February 2021

Published: 6 February 2021

Publisher's Note: MDPI stays neutral with regard to jurisdictional claims in published maps and institutional affiliations.

Copyright: (c) 2021 by the authors. Licensee MDPI, Basel, Switzerland. This article is an open access article distributed under the terms and conditions of the Creative Commons Attribution (CC BY) license (https:/ / creativecommons.org/licenses/by/ $4.0 /)$.

\begin{abstract}
Okara, a by-product of tofu or soymilk, is rich in dietary fibers (DFs) that are mostly insoluble. A wet-type grinder (WG) system was used to produce nanocellulose (NC). We hypothesized that the WG system would increase the dispersion performance and viscosity of okara. These properties of WG-treated okara improve the gel-forming ability of soybean proteins. Here, the suspensions of $2 \mathrm{wt} \%$ okara were treated with WG for different passages (1, 3, and 5 times). The particle size distribution (PSD) and viscosity of WG-treated okara decreased and increased, respectively, with different passages. The five-time WG-treated okara homogeneously dispersed in water after $24 \mathrm{~h}$, whereas untreated okara did not. The breaking stress, strain, and water holding capacity of soybean protein isolate (SPI) gels increased upon the addition of WG-treated okara. This effect increased as the number of WG treatments increased. The breaking stress and strain of SPI gels to which different concentrations of the five-time WG-treated okara were added also increased with increasing concentrations of WG-treated okara. These results suggest that NC technology can improve the physicochemical properties of okara and are useful in the development of protein gel-based foods.
\end{abstract}

Keywords: okara; wet-type grinder; nanocelluloses; soy protein isolate; heat-induced gel

\section{Introduction}

Okara is a by-product of tofu or soymilk and rich in insoluble dietary fibers (DFs), which mostly consist of cellulose and hemicellulose [1-3]. Thus, improving the physicochemical properties of okara for various food applications is of great importance [4-8]. In previous studies, Huang et al. [4] modified okara using enzyme, chemical, and homogenization methods. All treatments improved the swelling capacity of okara, and the homogenization and enzyme-treatment were the most appropriate methods to improve the solubility of okara [4]. Dai et al. [9] also investigated the effects of modified okara consumption on body weight, serum metabolites, and fatty acid compositions in high fat-fed mice. Intake of the modified okara suppressed body weight gain, changes in metabolites, and fatty acid compositions in mouse sera compared to untreated mice [9]. Pérez-López et al. [5] studied the treatment with high hydrostatic pressure (HHP) and food-grade enzymes to increase the amount of soluble DF in okara. HHP and enzyme treatment increased the amount of soluble DF up to $13.53 \pm 0.3 \%$ [5]. Additionally, the effects of dietary HHP and enzyme-treated okara were examined in high fat-fed mice. HHP and enzyme-treated okara intake inhibited the increase in body and liver weights and controlled triglycerides and urea in plasma [10]. Ullah et al. [6] examined okara by high-energy wet milling and reduced the particle size of okara from $66.7 \mu \mathrm{m}$ to $544.3 \mathrm{~nm}$. This research group also studied the effect of nanosized okara on the gel properties of tofu [11] and silver carp surimi [12]. These studies demonstrated that pulverization can improve the physicochemical and functional properties of okara. However, the usefulness of pulverized okara in food applications is unclear. 
Water jet (WJ) and wet-type grinder (WG) systems are commonly used to produce nanocelluloses (NCs) [13-15]. The WJ system involves a high-pressure water jet technology that can pulverize sample suspensions in water up to $245 \mathrm{MPa}$. With the WJ-treatment at $245 \mathrm{MPa}$ in ten cycles, the crystalline cellulose (CC) suspended in water $(1 \% w / v)$ was delaminated, which indicates a highly viscous and a gel-like form. Scanning transmission electron microscopy images showed that width of the WJ-treated CC fiber was reduced to $25 \mathrm{~nm}$, indicating the formation of NC. This system also decreased the crystal structure of cellulose and tripled the hydrolysis efficiency of cellulase [16]. In our previous study, we used a WJ system, pulverized okara, and microcrystalline cellulose (MCC). The WJtreated okara and MCC had high dispersion performance and viscosity. The WJ-treated okara also showed greater inhibition of $\alpha$-amylase compared to that presented by MCC and cellulose. Furthermore, WJ-treated okara increased butyrate production by Roseburia intestinalis, which is one of the dominant species of human gut microbiota [7]. In our other studies, we investigated the effects of dietary NC produced by the WJ system on obesity and the gut microbiota of mice fed a high-fat diet $[17,18]$. NC consumption suppressed weight gain and fat accumulation [17]. The consumption of NC increased voluntary wheelrunning activity, inhibited the increase in body weight, and controlled the balance of gut microbiota in mice [18]. Ifuku et al. reported methods for the preparation of chitin and chitosan nanofibers (CNFs) using the WJ system $[19,20]$. The authors also demonstrated the beneficial effects of CNFs as functional foods in animal models [21]. These results show that the WJ system is a useful method to not only produce NC, but also to develop ingredients for functional foods. However, to process samples with the WJ system, they should have a particle size of less than $0.1 \mathrm{~mm}$. In contrast, the WG system passes the cellulose dispersion in water between two grinding stone disks, where the distance between the two disks can be adjusted. The zero position between the two disks is the contact position, and a negative gap between the two disks can be set under wet conditions to increase the fibrillation efficiency. An advantage of this system is its ability to avoid clogging that often occurs in a high-pressure homogenizer and the WJ system [22-24]. These reports indicate that the WG system is more applicable than the WJ system in the food industry.

Processed soybean foods, such as tofu and soymilk, are often present in human diets. However, these products contain low DFs, although soybeans themselves contain a high percentage of DFs (15.6-17.9\%). For this reason, there are some reports where tofu has been prepared from whole soybeans, but not soymilk [25]. In addition, the replacement of animal proteins with plant proteins has been driven by the concept of sustainability assurance in food production. Soybean-based ingredients are used in many meat analog products currently in the market [26-28]. Therefore, the gel-forming ability of soybean proteins is the most important property for the development of processed soybean foods [29,30].

We hypothesized that the WG system would increase the dispersion performance and viscosity of okara. These properties of WG-treated okara improve the gel-forming ability of soybean proteins. To test this hypothesis, the aim of this study was to explore the effect of WG-treated okara on the gel-forming ability of soybean proteins. We examined (1) okara pulverization using the WG system and (2) the effects of WG-treated okara on soybean protein isolate (SPI) gel properties.

\section{Materials and Methods}

\subsection{Materials}

Defatted okara (Newproplus 1000) and SPI (Fujipro F) were obtained from Fuji Oil Co., Ltd. (Izumisano, Japan). According to the manufacturer, Newproplus 1000 contains $6.0 \%$ water, $20.7 \%$ protein, $0.2 \%$ fat, $69.1 \%$ carbohydrate $(63.7 \%$ dietary fiber), and $4.0 \%$ ash. Fujipro F contains $5.0 \%$ water, $86.3 \%$ protein, $0.2 \%$ fat, $4.0 \%$ carbohydrate, and $4.5 \%$ ash. 


\subsection{Preparation of WG-Treated Okara}

Dispersion of $2 \mathrm{wt} \%$ okara in distilled water was pulverized using a Supermasscolloider (MKCA6-2; Masuko Sangyo Co., Ltd., Kawaguchi, Japan) with a $-0.15 \mathrm{~mm}$ gap at $1540 \mathrm{rpm}$ of the stone disk.

\subsection{Viscosity of WG-Treated Okara}

The viscosity was measured using a B-type viscometer (Toyo Keiki Inc., Tokyo, Japan) with a No. 1 rotor at a shear rate of $0.5 \mathrm{~s}^{-1}$ at $25^{\circ} \mathrm{C}$ [1]. The data represent the average of three measurements for each sample.

\subsection{Particle Size Distribution (PSD) of WG-Treated Okara}

The particle size distribution (PSD) was measured using a laser scattering PSD analyzer (LA-960, Horiba, Kyoto, Japan) with a relative refractive index of 1.60 [7]. The data represent the average of two measurements for each sample.

\subsection{Preparation of SPI Gel}

SPI gels were prepared as described in our previous study [31]. SPI powder $(6 \mathrm{wt} \%)$ was hydrated by mixing with a WG-treated okara slurry and dispersed using a homogenizer (IKA Ultra-Turrax T8 Disperser, IKA Works, Inc., Staufen im Breisgau, Germany). After adding $0.25 \%$ magnesium chloride $\left(\mathrm{MgCl}_{2}\right)$ and sodium chloride $(\mathrm{NaCl})$, the slurry was poured into a stainless mold (inner diameter $20 \mathrm{~mm}$ and height $20 \mathrm{~mm}$ ), whose inside surface was covered with silicon grease. A silicon rubber sheet and a polycarbonate plate $(25 \times 25 \mathrm{~mm})$ were placed on both the top and bottom of the mold and then were tightly sealed using two rubber bands. The molds were heated at $80^{\circ} \mathrm{C}$ for $30 \mathrm{~min}$ in a water bath (FSGPD05, Fisher Scientific International Inc., Hampton, NH, USA).

\subsection{Compression Measurements of SPI Gels Containing WG-Treated Okara}

Compression measurements were performed using a texture analyzer (TA-XT2iHR, Stable Micro Systems) attached to a $5 \mathrm{~kg}$ load cell at $25^{\circ} \mathrm{C}$. A cylindrical plunger with a diameter of $50 \mathrm{~mm}$ was used and the compression speed was $1 \mathrm{~mm} / \mathrm{s}$. In each experiment, at least six gels were examined for each point.

\subsection{Water Holding Capacity (WHC) of SPI Gels Containing WG-Treated Okara}

The sample mixtures were prepared as described in Section 2.5. Briefly, SPI was mixed with a WG-treated okara slurry and $0.25 \% \mathrm{MgCl}_{2}$ and $1 \% \mathrm{NaCl}$ were added. Water content (W) and water holding capacity (WHC) were measured using a modification of a previously reported method [32]. An aluminum cup was weighed $\left(m_{0}\right)$ and the sample mixture was added and then weighed again $\left(m_{1}\right)$. The cup was heated using a drying oven at $105^{\circ} \mathrm{C}$ overnight, cooled to $25^{\circ} \mathrm{C}$ in a desiccator, and then weighed $\left(m_{2}\right)$. The $\mathrm{W}$ was calculated using Equation (1):

$$
\mathrm{W}=1-\frac{m 2-m 0}{m 1-m 0}
$$

A $1.5 \mathrm{~mL}$ microtube was weighed $\left(m_{3}\right)$ and sample mixtures were added and then weighed $\left(m_{4}\right)$. The gel was formed by heating at $80{ }^{\circ} \mathrm{C}$ for $30 \mathrm{~min}$ and the tube was centrifuged at $1000 \times g$ for $10 \mathrm{~min}$. After centrifugation, the upper phase was weighed $\left(m_{5}\right)$. WHC was calculated using the following Equation (2):

$$
\mathrm{WHC}(\%)=100 \frac{(m 4-m 3) \mathrm{W}-m 5}{(m 4-m 3) \mathrm{W}}
$$

The data represent the average of three measurements for each sample. 


\subsection{Statistical Analyses}

Data represent mean \pm standard deviation (SD). Statistical significance was calculated using one-way analysis of variance (ANOVA), followed by Tukey's post-hoc test, using the Origin 2020b software (Origin Lab, Northampton, MA, USA). Data were considered statistically significant at $p<0.05$.

\section{Results}

\subsection{PSD, Viscosity, and Dispersion Ability of WG-Treated Okara}

To investigate the impact of WG system on okara properties, we examined PSD, viscosity, and dispersion ability. The dispersions of $2 \mathrm{wt} \%$ okara in water were treated with the WG system after different passages (1,3, and 5 times). The PSD median sizes of okara decreased with increasing passages. In contrast, the okara viscosity increased with increasing passages (Table 1). The WG-treated okara was dispersed homogeneously in water with increasing passages (1,3, and 5 times) after $24 \mathrm{~h}$ (Figure 1$)$. These results indicate that the viscosity and dispersion ability of WG-treated okara increased with increasing number of passages.

Table 1. Median sizes from particle size distributions and viscosities of wet-type grinder-treated okara $(2 \mathrm{wt} \%)$ at a shear rate of $0.5 \mathrm{~s}^{-1}$ after different passages $\left(25^{\circ} \mathrm{C}\right)$.

\begin{tabular}{ccccc}
\hline & Untreated & One Passage & Three Passages & Five Passages \\
\hline Median size $(\mu \mathrm{m})$ & 68.5 & 13.5 & 9.9 & 8.9 \\
Viscosity $(\mathrm{mPas})$ & $10 \pm 4^{\mathrm{a}}$ & $40 \pm 8^{\mathrm{b}}$ & $70 \pm 10^{\mathrm{c}}$ & $120 \pm 16^{\mathrm{d}}$ \\
\hline
\end{tabular}

Different letters indicate significant differences $(p<0.05)$.

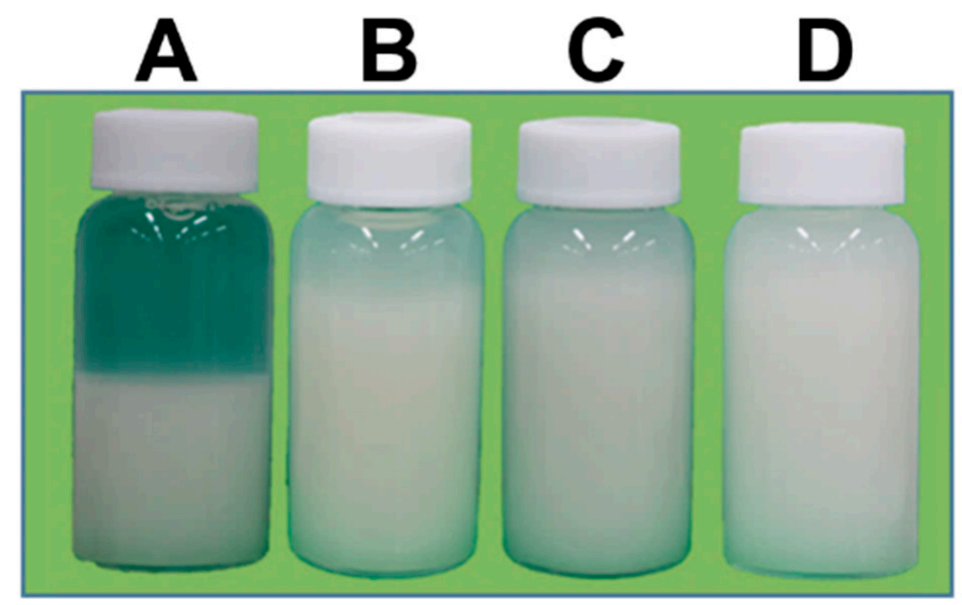

Figure 1. Wet-type grinder (WG)-treated okara in water after $24 \mathrm{~h}$. Okara (2 wt $\%)$ was treated with the WG for different passages. (A) untreated; (B) one passage; (C) three passages; (D) five passages.

\subsection{Effects of $\mathrm{NaCl}$ Concentrations on SPI Gels}

We examined the effect of $\mathrm{NaCl}$ concentration on the rheological properties of $6 \%$ SPI gels, because $\mathrm{NaCl}$ was required for the gel formation. We previously described the pronounced effect of $\mathrm{NaCl}$ concentration on SPI gel properties [33]. The breaking stress of the SPI gels at $0.2 \%, 0.5 \%, 1.0 \%$, and $1.5 \% \mathrm{NaCl}$ showed values of $160 \pm 20 \mathrm{~Pa}, 400 \pm 40 \mathrm{~Pa}$, $270 \pm 20 \mathrm{~Pa}$, and $190 \pm 25 \mathrm{~Pa}$, respectively (Figure 2a), while the values for the breaking strain of these SPI gels were $32.9 \pm 2.0 \%, 42.0 \pm 1.5 \%, 37.0 \pm 0.7 \%$, and $34.0 \pm 2.3 \%$, respectively (Figure $2 \mathrm{~b}$ ). The breaking stress and strain of the SPI gels increased with an increase in the $\mathrm{NaCl}$ concentration up to $0.5 \%$ and then decreased. 


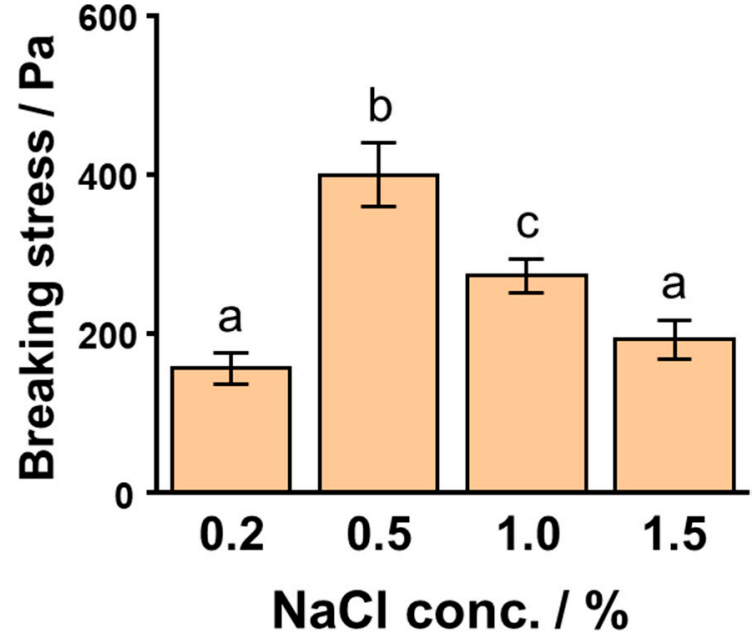

(a)

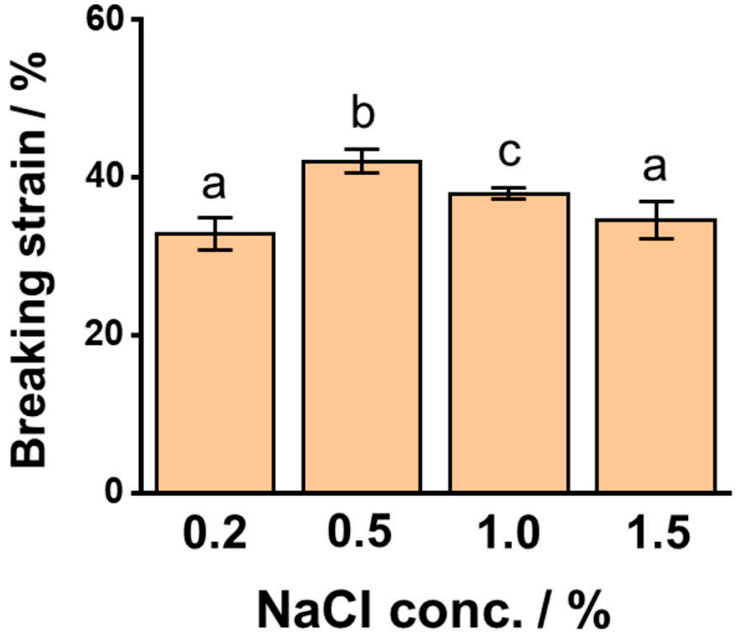

(b)

Figure 2. The breaking stress (a) and strain (b) of $6 \%$ soybean protein isolate (SPI) gels at different concentrations of sodium chloride $(\mathrm{NaCl})$. Different letters indicate significant differences $(p<0.01)$.

\subsection{Effects of WG-Treated Okara, with Varying Passages, on SPI Gels}

To clarify the effect of WG-treated okara with different passages in the WG system on SPI gels, we studied the gel properties of SPI at $1.0 \%$ and $1.5 \% \mathrm{NaCl}$ (Figure 3 ). We examined the breaking stress and strain of $6 \%$ SPI gels at $1.0 \% \mathrm{NaCl}$ with $1 \mathrm{wt} \%$ okara treated with WG after different passages. The breaking stress of SPI gels to which untreated okara and WG-treated okara after one, three, and five passages were added and showed values of $365 \pm 43 \mathrm{~Pa}, 360 \pm 32 \mathrm{~Pa}, 495 \pm 70 \mathrm{~Pa}$, and $529 \pm 66 \mathrm{~Pa}$, respectively (Figure 3a), while the breaking strain of these SPI gels was $40.4 \pm 2.1 \%, 40.9 \pm 0.7 \%, 43.6 \pm 1.9 \%$, and $44.0 \pm 0.6 \%$, respectively (Figure $3 b$ ). The breaking stress and strain of SPI gels containing three- and five-time WG-treated okara were significantly higher than those of gels with untreated okara $(p<0.01)$.

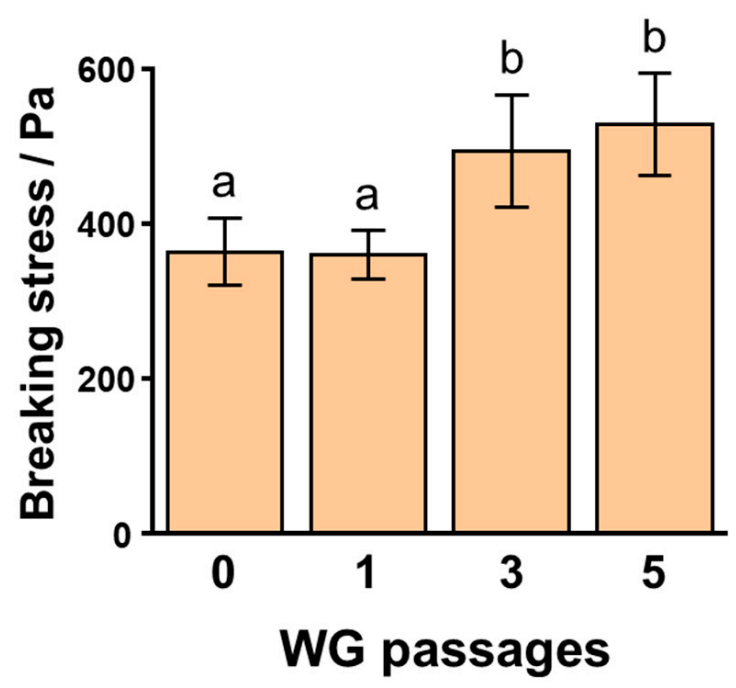

(a)

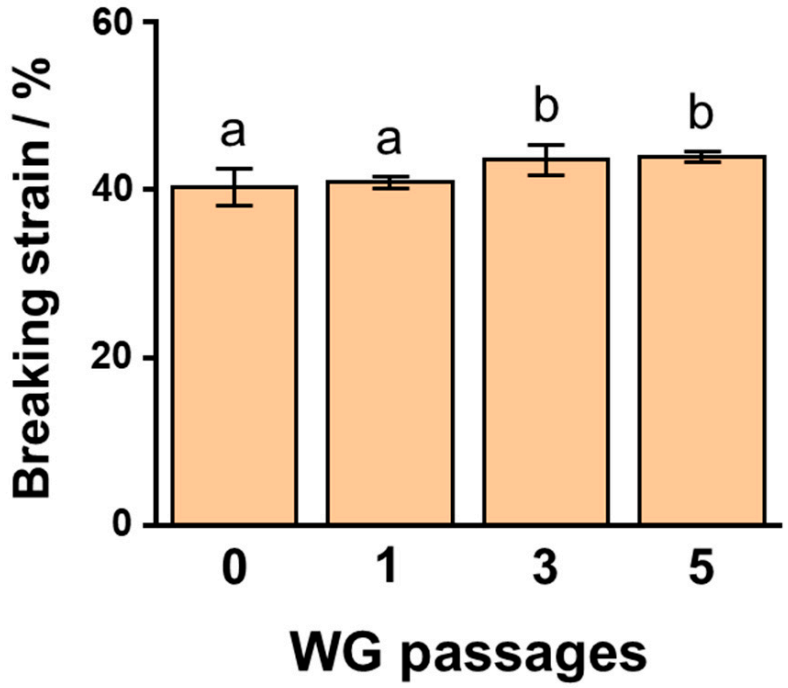

(b)

Figure 3. Cont. 


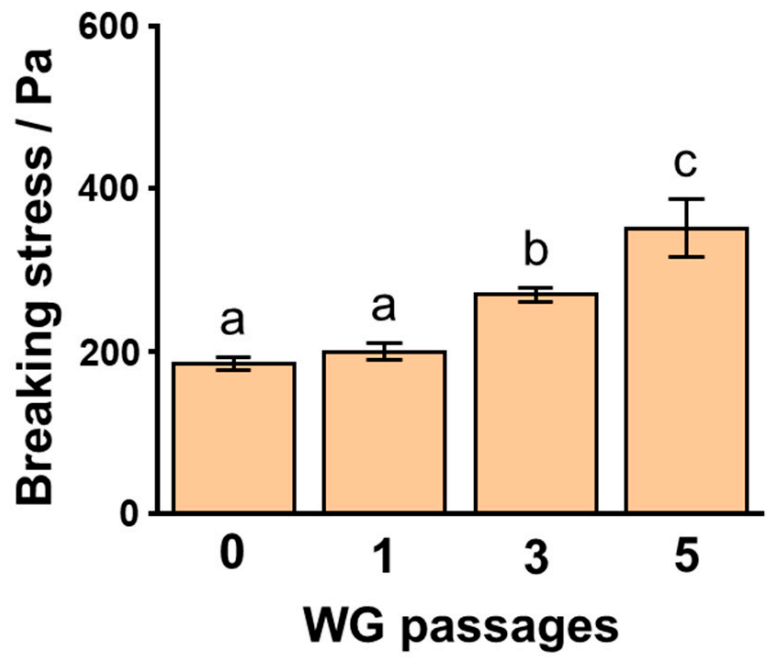

(c)

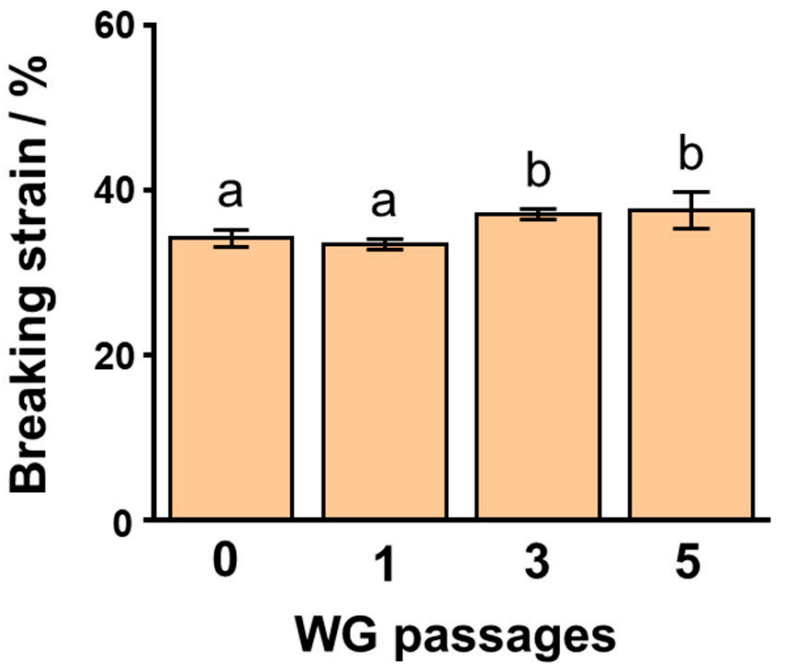

(d)

Figure 3. The breaking stress $(\mathbf{a}, \mathbf{c})$ and strain $(\mathbf{b}, \mathbf{d})$ of $6 \%$ soybean protein isolate (SPI) gels to which $1 \%$ wet-type grinder (WG)-treated okara was added after different passages at $1.0 \%(\mathbf{a}, \mathbf{b})$ and $1.5 \%(\mathbf{c}, \mathbf{d})$ sodium chloride concentration. Different letters indicate significant differences $(p<0.01)$.

We also measured the breaking stress and strain of $6 \%$ SPI gels at $1.5 \% \mathrm{NaCl}$ concentration with $1 \mathrm{wt} \%$ okara treated with WG after varying the number of passages. The breaking stress of SPI gels, to which untreated okara and WG-treated okara after one, three, and five passages were added, showed values of $190 \pm 8 \mathrm{~Pa}, 200 \pm 10 \mathrm{~Pa}$, $270 \pm 9 \mathrm{~Pa}$, and $360 \pm 35 \mathrm{~Pa}$, respectively (Figure 3c), while the values for the breaking strain of these SPI gels were $34.2 \pm 1.1 \%, 33.5 \pm 0.7 \%, 37.1 \pm 0.6 \%$, and $37.6 \pm 2.2 \%$, respectively (Figure 3d). The breaking stress and strain of the SPI gels containing three and five-time WG-treated okara were significantly higher than those of the gels with untreated okara $(p<0.01)$.

We determined the WHC of $6 \%$ SPI gels at $1.0 \% \mathrm{NaCl}$ containing $1 \mathrm{wt} \%$ okara treated with WG after different passages. The WHC of SPI gels after the addition of untreated okara and WG-treated okara following one, three, and five passages were $93.30 \pm 0.75 \%$, $94.12 \pm 1.05 \%, 95.20 \pm 0.97 \%$, and $96.16 \pm 0.87 \%$, respectively (Figure 4 ). The WHC of SPI gels consisting of three- and five-time WG-treated okara were significantly higher than those of SPI gels with untreated okara $(p<0.01)$.

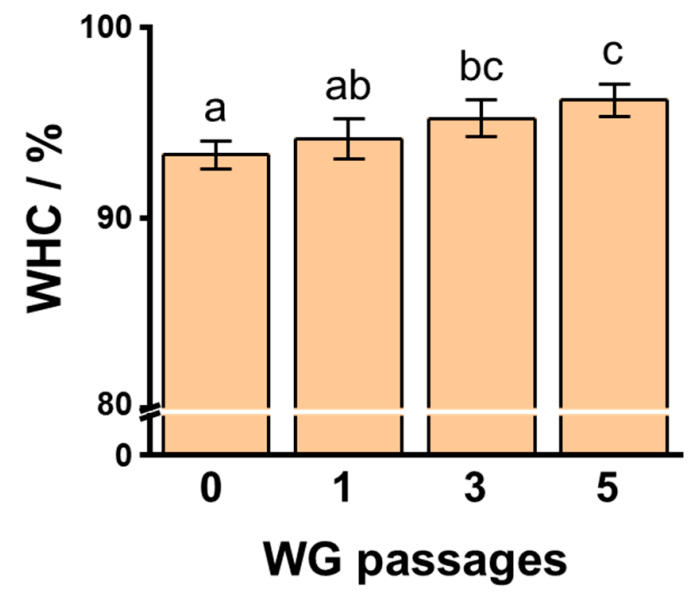

Figure 4. The water holding capacity (WHC) of $6 \%$ soybean protein isolate (SPI) gels to which $1 \%$ wet-type grinder (WG)-treated okara was added after different passages at $1.0 \%$ sodium chloride concentration. Different letters indicate significant differences $(p<0.01)$. 


\subsection{Effects of WG-Treated Okara Concentration on SPI Gels}

To clarify the effect of WG-treated okara concentration on SPI gels, we studied the gel properties using compression measurements. We determined the breaking stress and strain of $6 \%$ SPI gels to which different concentrations of the five-time WG-treated okara were added at $1.0 \% \mathrm{NaCl}$. The breaking stress of SPI gels after addition of $0 \%, 0.5 \%, 0.75 \%$, and 1\% WG-treated okara were $257 \pm 22 \mathrm{~Pa}, 412 \pm 15 \mathrm{~Pa}, 513 \pm 34 \mathrm{~Pa}$, and $531 \pm 61 \mathrm{~Pa}$, respectively (Figure 5a), whereas the breaking strain of these SPI gels were $36.0 \pm 0.9 \%$, $39.1 \pm 0.4 \%, 40.7 \pm 0.8 \%$, and $42.0 \pm 2.5 \%$, respectively (Figure $5 \mathrm{~b}$ ). The breaking stress and strain of SPI gels significantly increased with increasing concentration of WG-treated okara $(p<0.01)$.

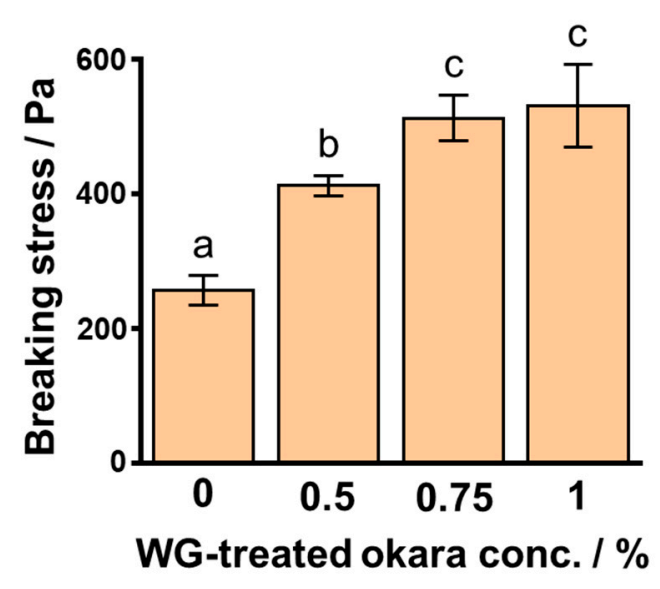

(a)

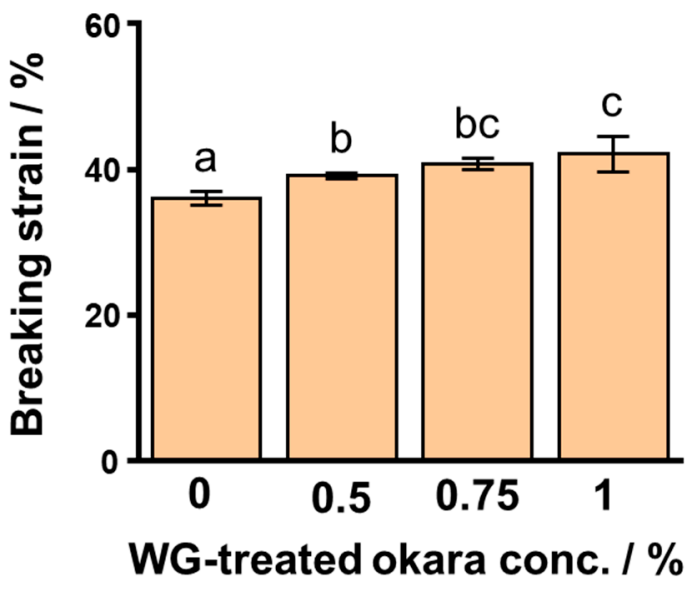

(b)

Figure 5. The breaking stress (a) and strain (b) of $6 \%$ soybean protein isolate (SPI) gels at $1.0 \% \mathrm{NaCl}$ with the addition of fivetime wet-type grinder-treated okara at different concentrations. Different letters indicate significant differences $(p<0.01)$.

\section{Discussion}

The results of this study show that WG can be a useful technology for improving the physicochemical properties of okara, such as dispersion ability and viscosity. In addition, the WG-treated okara improved SPI gel properties, such as breaking stress and strain, as well as WHC.

In the present study, the median PSD size decreased with increasing passages up to the third time, and there was little difference in the median sizes of WG-treated okara after three and five passages. The PSD median sizes were reduced to $8.9 \mu \mathrm{m}$ by WG treatment after five passages. The viscosity and dispersion performance after $24 \mathrm{~h}$ of WG treatment of okara increased with an increase in the number of passages. In our previous study, we had used the WJ system to improve the physicochemical properties of okara. The dry grinder (DG) treatment reduced the PSD median sizes of okara from $61.5 \mu \mathrm{m}$ to $39.7 \mu \mathrm{m}$ and the WJ system decreased its size to $6.6 \mu \mathrm{m}$. We determined the dispersion performance by placing the samples for $24 \mathrm{~h}$. The untreated and DG-treated okara dispersions produced a precipitate after $24 \mathrm{~h}$, whereas the WJ-treated okara did not precipitate [7]. These results indicate that okara can be enhanced by both systems in terms of the viscosity and dispersion ability, although the WJ system atomizes okara more efficiently than the WG system. Additionally, Iwamoto et al. [23] investigated pulp fiber delamination using the WG system. The images of the scanning electron microscope showed many microsized fibers by one passage, and the size of the fibers reduced with further treatments. Most fibers became nano-sized after five passages; however, further passages did not change the fiber morphology. Our present results are in line with those obtained in the study by Iwamoto et al. [23]. 
In this study, $\mathrm{MgCl}_{2}$, used in tofu production, was used as a coagulant. The heatinduced SPI gels did not form without the addition of $\mathrm{NaCl}$, and the breaking stress and strain of the SPI gels increased up to a $0.5 \% \mathrm{NaCl}$ concentration and then decreased. These results show that ionic interactions are important for the formation and texture of SPI gels. This phenomenon could be due to ionic repulsion and attraction, which decrease with an increase in the ionic strength of the system [30].

Our study showed that the addition of WG-treated okara increased the breaking stress and strain and WHC of SPI gels. This effect increased as the number of WG treatments increased. The breaking stress and strain of WG-treated okara and SPI gels also increased with an increase in concentrations of five-time WG-treated okara. In a previous study, Liu et al. [25] applied ultra-high-pressure homogenization (UHPH) to soybean flour for tofu making. UHPH reduced the particle size of soybean flour and the hardness of tofu prepared from UHPH-treated soybean flour was similar to that of the control tofu. In other previous studies, Ullah et al. [11] studied the effect of nano-sized $(370 \mathrm{~nm})$ and micro-sized $(110 \mu \mathrm{m})$ okara on the gel properties of tofu. Soymilk was mixed with different volumetric ratios of nano-sized and micro-sized okara suspensions. Nano-sized okara tofu showed more whiteness than micro-sized okara tofu. Nano-sized okara was also distributed well in the gel matrices and provided less gritty mouthfeel than micro-sized okara. This research group also investigated the effects of nano-sized okara on the gel properties of silver carp surimi. The breaking force and penetration distance of the surimi gels increased with increasing concentration of nano-sized okara. Light microscopy images showed that nanosized okara, but not micro-sized okara, distributed well in surimi gels [12]. These results suggest that dehydration and filler effects are possible reasons for controlling gel properties. The increased WHC of SPI gels could be attributed to the high water absorption ability of WG-treated okara. The higher water absorption ability corresponds to a higher dehydration effect in the gel matrix. The smaller particle size of okara generated by WG treatments could remain in the gel matrix without interrupting it, which corresponds to the filler effects. However, the underlying mechanism for this could not be clarified in this study and thus might warrant further investigation.

In processed surimi and meat products, the $\mathrm{NaCl}$ concentration ranges from $1 \%$ to $3 \%$ [34,35]. In this study, the breaking stress and strain of SPI gels were improved by adding WG-treated okara at $\mathrm{NaCl}$ concentrations of $1.0 \%$ and $1.5 \%$. This effect increased by increasing the WG-treated okara concentrations in the range $0.5 \%-1.0 \%$. The WHC was also improved by the addition of WG-treated okara. Our findings suggest that WG-treated okara improves processed food products. Meanwhile, the effects of DFs and resistant starch on protein gels of surimi and meat have been investigated for added health benefits [36-38]. Alakhrash et al. [36] studied the effects of oat bran on the physicochemical properties of Alaska pollock surimi gels. Their investigation demonstrated that incorporating oat bran into surimi products did not compromise quality [36]. In another study on surimi, Yang et al. [37] investigated the effects of a highly resistant rice starch (RS) on the properties of surimi gels from grass carp. The optimum RS addition level was proposed to be $4 \%$ $w / w$ [37]. Additionally, in a study on meat products, Zhao et al. [38] studied the effects of regenerated cellulose $(\mathrm{RC})$ fibers on myofibrillar protein gels from lean pork. They showed that the textural properties and WHC of myofibrillar protein gels were enhanced with the RC fibers [38]. These studies could contribute to the development of protein-based gel foods not only to improve their textural and physical properties, but also to add to their health benefits.

\section{Conclusions}

In this study, okara was atomized using a WG system to produce NCs. We treated okara with a WG system at a varying number of passages. The median PSD size decreased with an increase in the WG treatment passages up to the third time and was reduced to $8.9 \mu \mathrm{m}$ by the fifth time. The viscosity and dispersion performance of okara $24 \mathrm{~h}$ post WG-treatment increased with an increase in the number of passages. These results 
demonstrated that the physicochemical properties of okara could be enhanced by using the WG system.

The rheological properties and WHC of SPI gels improved upon the addition of WG-treated okara at $1.0 \%$ and $1.5 \% \mathrm{NaCl}$ concentrations, which are used in surimi and processed meat products. This effect was increased with an increase in the concentration of WG-treated okara. The present study demonstrated that the WG-treated okara could be used for the development of protein gel-based foods to enhance gel properties.

Author Contributions: Conceptualization, T.N. and K.N.; methodology, T.N.; validation, Y.A., K.N., and T.N.; formal analysis, T.N.; investigation, Y.A.; data curation, T.N.; writing-original draft preparation, T.N.; writing-review and editing, T.N.; visualization, T.N.; supervision, K.N.; project administration, T.N.; funding acquisition, T.N. All authors have read and agreed to the published version of the manuscript.

Funding: This research was funded by the Salt Science Research Foundation, grant number 1945 and the Fuji Foundation for Protein Research.

Institutional Review Board Statement: Not applicable.

Informed Consent Statement: Not applicable.

Data Availability Statement: Not applicable.

Conflicts of Interest: The authors declare no conflict of interest.

\section{References}

1. Nagano, T.; Arai, Y.; Yano, H.; Aoki, T.; Kurihara, S.; Hirano, R.; Nishinari, K. Improved physicochemical and functional properties of okara, a soybean residue, by nanocellulose technologies for food development-A review. Food Hydrocoll. 2020, $109,105964$. [CrossRef]

2. O'Toole, D.K. Characteristics and use of okara, the soybean residue from soy milk production-A review. J. Agric. Food Chem. 1999, 47, 363-371. [CrossRef]

3. Li, S.; Zhu, D.; Li, K.; Yang, Y.; Lei, Z.; Zhang, Z. Soybean curd residue: Composition, utilization, and related limiting factors. ISRN Ind. Eng. 2013, 2013, 1-8. [CrossRef]

4. Huang, S.; He, Y.; Zou, Y.; Liu, Z. Modification of insoluble dietary fibres in soya bean okara and their physicochemical properties. Int. J. Food Sci. Technol. 2015, 50, 2606-2613. [CrossRef]

5. Pérez-López, E.; Mateos-Aparicio, I.; Rupérez, P. High hydrostatic pressure aided by food-grade enzymes as a novel approach for Okara valorization. Innov. Food Sci. Emerg. Technol. 2017, 42, 197-203. [CrossRef]

6. Ullah, I.; Yin, T.; Xiong, S.; Zhang, J.; Din, Z.-U.; Zhang, M. Structural characteristics and physicochemical properties of okara (soybean residue) insoluble dietary fiber modified by high-energy wet media milling. LWT 2017, 82, 15-22. [CrossRef]

7. Nagano, T.; Hirano, R.; Kurihara, S.; Nishinari, K. Improved effects of okara atomized by a water jet system on alpha-amylase inhibition and butyrate production by Roseburia intestinalis. Biosci. Biotechnol. Biochem. 2020, 84, 1467-1474. [CrossRef] [PubMed]

8. Fayaz, G.; Plazzotta, S.; Calligaris, S.; Manzocco, L.; Nicoli, M.C. Impact of high pressure homogenization on physical properties, extraction yield and biopolymer structure of soybean okara. LWT 2019, 113, 108324. [CrossRef]

9. Dai, B.; Huang, S.; Deng, Y. Modified insoluble dietary fibers in okara affect body composition, serum metabolic properties, and fatty acid profiles in mice fed high-fat diets: An NMR investigation. Food Res. Int. 2019, 116, 1239-1246. [CrossRef]

10. Pérez-López, E.; Veses, A.M.; Redondo, N.; Tenorio-Sanz, M.D.; Villanueva, M.J.; Redondo-Cuenca, A.; Marcos, A.; Nova, E.; Mateos-Aparicio, I.; Rupérez, P. Soybean okara modulates gut microbiota in rats fed a high-fat diet. Bioact. Carbohydr. Diet. Fibre 2018, 16, 100-107. [CrossRef]

11. Ullah, I.; Hu, Y.; You, J.; Yin, T.; Xiong, S.; Din, Z.-U.; Huang, Q.; Liu, R. Influence of okara dietary fiber with varying particle sizes on gelling properties, water state and microstructure of tofu gel. Food Hydrocoll. 2019, 89, 512-522. [CrossRef]

12. Yin, T.; Yao, R.; Ullah, I.; Xiong, S.; Huang, Q.; You, J.; Hu, Y.; Shi, L. Effects of nanosized okara dietary fiber on gelation properties of silver carp surimi. LWT 2019, 111, 111-116. [CrossRef]

13. Lu, H.; Gui, Y.; Zheng, L.; Liu, X. Morphological, crystalline, thermal and physicochemical properties of cellulose nanocrystals obtained from sweet potato residue. Food Res. Int. 2013, 50, 121-128. [CrossRef]

14. García, A.; Gandini, A.; Labidi, J.; Belgacem, N.; Bras, J. Industrial and crop wastes: A new source for nanocellulose biorefinery. Ind. Crops Prod. 2016, 93, 26-38. [CrossRef]

15. Costa, A.L.R.; Gomes, A.; Tibolla, H.; Menegalli, F.C.; Cunha, R.L. Cellulose nanofibers from banana peels as a Pickering emulsifier: High-energy emulsification processes. Carbohydr. Polym. 2018, 194, 122-131. [CrossRef]

16. Watanabe, Y.; Kitamura, S.; Kawasaki, K.; Kato, T.; Uegaki, K.; Ogura, K.; Ishikawa, K. Application of a water jet system to the pretreatment of cellulose. Biopolymers 2011, 95, 833-839. [CrossRef] 
17. Nagano, T.; Yano, H. Dietary cellulose nanofiber modulates obesity and gut microbiota in high-fat-fed mice. Bioact. Carbohydr. Diet. Fibre 2020, 22, 100214. [CrossRef]

18. Nagano, T.; Yano, H. Effect of dietary cellulose nanofiber and exercise on obesity and gut microbiota in mice fed a high-fat-diet. Biosci. Biotechnol. Biochem. 2020, 84, 613-620. [CrossRef] [PubMed]

19. Ifuku, S.; Yamada, K.; Morimoto, M.; Saimoto, H. Nanofibrillation of dry chitin powder by star burst system. J. Nanomater. 2012, 2012, 645624. [CrossRef]

20. Dutta, A.K.; Kawamoto, N.; Sugino, G.; Izawa, H.; Morimoto, M.; Saimoto, H.; Ifuku, S. Simple preparation of chitosan nanofibers from dry chitosan powder by the Star Burst system. Carbohydr. Polym. 2013, 97, 363-367. [CrossRef]

21. Azuma, K.; Ifuku, S. Nanofibers based on chitin: A new functional food. Pure Appl. Chem. 2016, 88, 605-619. [CrossRef]

22. Iwamoto, S.; Nakagaito, A.N.; Yano, H.; Nogi, M. Optically transparent composites reinforced with plant fiber-based nanofibers. Appl. Phys. A 2005, 81, 1109-1112. [CrossRef]

23. Iwamoto, S.; Nakagaito, A.N.; Yano, H. Nano-fibrillation of pulp fibers for the processing of transparent nanocomposites. Appl. Phys. A 2007, 89, 461-466. [CrossRef]

24. Nechyporchuk, O.; Belgacem, M.N.; Bras, J. Production of cellulose nanofibrils: A review of recent advances. Ind. Crops Prod. 2016, 93, 2-25. [CrossRef]

25. Liu, H.H.; Chien, J.T.; Kuo, M.I. Ultra high pressure homogenized soy flour for tofu making. Food Hydrocoll. 2013, 32, $278-285$. [CrossRef]

26. Pojić, M.; Mišan, A.; Tiwari, B. Eco-innovative technologies for extraction of proteins for human consumption from renewable protein sources of plant origin. Trends Food Sci. Technol. 2018, 75, 93-104. [CrossRef]

27. Jones, O.G. Recent advances in the functionality of non-animal-sourced proteins contributing to their use in meat analogs. Curr. Opin. Food Sci. 2016, 7, 7-13. [CrossRef]

28. Geerts, M.E.J.; Dekkers, B.L.; van der Padt, A.; van der Goot, A.J. Aqueous fractionation processes of soy protein for fibrous structure formation. Innov. Food Sci. Emerg. Technol. 2018, 45, 313-319. [CrossRef]

29. Nishinari, K.; Fang, Y.; Nagano, T.; Guo, S.; Wang, R. 6-Soy as a food ingredient. In Proteins in Food Processing, 2nd ed.; Yada, R.Y., Ed.; Woodhead Publishing: Sawston, UK, 2018; pp. 149-186.

30. Nagano, T.; Fukuda, Y.; Akasaka, T. Dynamic viscoelastic study on the gelation properties of $\beta$-conglycinin-rich and glycinin-rich soybean protein isolates. J. Agric. Food Chem. 1996, 44, 3484-3488. [CrossRef]

31. Nagano, T. Contribution of disulfide bonding to viscoelastic properties and microstructures of $11 \mathrm{~S}$ globulin gels from soybeans: Magnesium chloride-induced gels. Food Sci. Technol. Res. 2013, 19, 51-57. [CrossRef]

32. Peters, J.P.C.M.; Vergeldt, F.J.; Boom, R.M.; van der Goot, A.J. Water-binding capacity of protein-rich particles and their pellets. Food Hydrocoll. 2017, 65, 144-156. [CrossRef]

33. Nagano, T.; Tokita, M. Viscoelastic properties and microstructures of $11 \mathrm{~S}$ globulin and soybean protein isolate gels: Magnesium chloride-induced gels. Food Hydrocoll. 2011, 25, 1647-1654. [CrossRef]

34. Desmond, E. Reducing salt: A challenge for the meat industry. Meat Sci. 2006, 74, 188-196. [CrossRef] [PubMed]

35. Cando, D.; Herranz, B.; Borderias, A.J.; Moreno, H.M. Different additives to enhance the gelation of surimi gel with reduced sodium content. Food Chem. 2016, 196, 791-799. [CrossRef] [PubMed]

36. Alakhrash, F.; Anyanwu, U.; Tahergorabi, R. Physicochemical properties of Alaska pollock (Theragra chalcograma) surimi gels with oat bran. LWT 2016, 66, 41-47. [CrossRef]

37. Yang, Z.; Wang, W.; Wang, H.; Ye, Q. Effects of a highly resistant rice starch and pre-incubation temperatures on the physicochemical properties of surimi gel from grass carp (Ctenopharyn Odon Idellus). Food Chem. 2014, 145, 212-219. [CrossRef]

38. Zhao, Y.; Zhou, G.; Zhang, W. Effects of regenerated cellulose fiber on the characteristics of myofibrillar protein gels. Carbohydr. Polym. 2019, 209, 276-281. [CrossRef] 